\title{
PRAKTIK POLIGAMI DI BAWAH TANGAN DI DESA LADEN KABUPATEN PAMEKASAN
}

\author{
Abd. Warits dan Abd. Wahed \\ Jurusan Syari'ah dan Ekonomi STAIN Pamekasan, \\ Jln. Pahlawan KM. 04 Pamekasan, \\ email:warist@yahoo.co.id; awahed64@yahoo.com
}

\begin{abstract}
Abstrak:
Artikel ini membahas tentang praktik poligami yang dilakukan di Desa Laden tanpa ada niatan sebelumnya untuk melakukan poligami. Namun seiring dengan berjalannya waktu semuanya terjadi tanpa ada kesadaran yang disebabkan let $r e^{\prime}$. Perkawinan poligami yang dilakukan tanpa adanya sepengetahuan isteri yang pertama dan dilakukan di bawah tangan (ilegal) tidak sesuai dengan ketentuan Undang-Undang No. 1 Tahun 1974, sehingga banyak menimbulkan dampak negatif, bahkan melenceng dari tujuan perkawinan yang telah diatur dalam UU yang ada di Indonesia.
\end{abstract}

\begin{abstract}
:
This article discusses polygamy practice done in Laden village without having intention first to do it. But, by slow degrees it happens without being awareness because of let $r e^{\prime}$. Polygamy marriage which is done without the first wife's knowledge and done illegally is not suitable with the certainty of law, number 1 of 1974, so it causes many negative effects, even deviates from marriage purpose that have been arranged in the law of Indonesia.
\end{abstract}

Kata Kunci:

Poligami dan Let re' 


\section{Pendahuluan}

Perkawinan merupakan anugerah yang diberikan oleh Allah swt. kepada hambaNya (manusia) yang ada di bumi. Dan merupakan sunnah Rasulullah saw. yang termasuk dalam ajaran agama Islam yang dibawa oleh Rasulullah saw. Perkawinan merupakan ikatan lahir batin antara seorang lakilaki dan seorang wanita yang masing-masing sudah menjalin hubungan suami isteri yang sah menurut hukum agama dan hukum negara. ${ }^{1}$ Hal ini juga dalam rangka kebahagiaan hidup dan membangun keluarga yang sakinah, mawaddah warahmah dalam sinaran kasih sayang Ilahi. Sehingga pada akhirnya akan melahirkan keturunan yang suci, shaleh/shalehah. Sesuai dengan firman Allah swt. dalam kitab suciNya surat ar-Rum ayat 21:

Artinya: "Dan diantara tanda-tanda kekuasaan-Nya ialah Dia menciptakan untukmu isteri-isteri dari jenismu sendiri, supaya kamu cenderung dan merasa tenteram kepadanya, dan dijadikanNya diantaramu rasa kasih dan sayang. Sesungguhnya pada yang demikian itu benar-benar terdapat tanda-tanda bagi kaum yang berfikir."2

Menurut beberapa cendekiawan muslim, kata sakana berarti diam/tenangnya sesuatu yang bergejolak. Jadi sakana dalam konsep perkawinan agama Islam mempunyai arti ketenangan yang dinamis, yaitu ketenangan psikologis seseorang setelah menjalani kehidupan berumah tangga. Karena di dalam pernikahan ada cinta, kasih sayang, rasa yang tidak bisa ditemukan dan dirasakan di luar nikah. Kadang ada kalanya perasaan itu yang kemudian untuk mendorong seseorang untuk menikah. ${ }^{3}$ Itulah sebabnya seseorang butuh

1 Tihani dan Sohari Saharani, Fiqih Munakahat (Jakarta: PT. Raja GrafindoPersada, 2010), hlm. 6.

2 Departemen Agama, al-Qur'an dan Terjemahan (Surabaya: Alhidayah, 1998), hlm. 192.

${ }^{3}$ Fatihuddin Abul Yasin, Risalah Hukum Nikah (Surabaya: Tertib Terang, 2006), hlm. 16-17. 
diikat dalam ikatan yang sah sebagai ladang untuk menumbuhkan mawaddah warahmah. Tanpa perkawinan yang sah menurut agama dan Undang-Undang akan menumbuhkan suatu permasalahan di kemudian hari.

Adapun sah menurut agama, apabila terjadinya akad nikah antara kedua belah pihak laki-laki dan perempuan sesuai dengan yang disyari'atkan dalam agama Islam. Sementara dalam Undang-Undang Pokok Perkawinan dinyatakan bahwa dianggap sah apabila tiap-tiap perkawinan dicatat menurut peraturan perundang-undangan yang berlaku. Substansi dari sebuah pernikahan yaitu adanya kasih sayang, rasa cinta, kehormatan, pembelajaran, kerjasama antara satu sama lainnya dan memenuhi syarat yang dibenarkan menurut UndangUndang yang berlaku di Indonesia. ${ }^{4}$

Di dalam perkawinan, seorang suami maupun isteri dilatih untuk memiliki mental sportif dari naluri kemanusiaan yang sehat yang sejalan dengan perasaan hati dan pikiran. Pernikahan merupakan jalan untuk menumbuhkan keluarga yang damai, tenteram, ketenangan, dan penuh kasih sayang sebagaimana yang dicontohkan oleh Nabi Muhammad saw. Dimana beliau sebagai Rasul dan kepala keluarga yang mempunyai isteri lebih dari satu (berpoligami) selalu berlaku adil terhadap isteri-isteri Beliau. Apabila Beliau mau beristeri lagi, Beliau selalu meminta izin kepada isteri yang lainnya.

Memang banyak diantara perkawinan Nabi Muhammad saw. dilakukan karena bertujuan politik Islam demi memperlebar syiar Islam, semisal memberi semangat kepada janda yang ditinggalkan oleh suaminya karena ikut peperangan demi membela hukum Allah swt. dimana Nabi Muhammad saw. menikah dengan seorang wanita yang disukainya dan

\footnotetext{
${ }^{4}$ Sayyid Ahmad al-Musayyar, Fiqih Cinta Kasih; Rahasia Kebahagiaan Rumah Tangga (Jakarta: PT. Glora Aksara Pertama, 2008), hlm. 6.
} 
tidak melakukan pernikahan dengan wanita yang tidak disukainya. ${ }^{5}$

Namun laki-laki yang ada di dunia ini tidak sama dengan Rasullah saw. dalam membina keluarganya yang lebih dari satu orang (poligami). Seperti yang difirmankan oleh Allah swt. dalam al-Quran surat an-Nisa'ayat 3:

Artinya: "Dan jika kamu takut tidak akan dapat berlaku adil terhadap (hak-hak) perempuan yang yatim (bilamana kamu mengawininya), maka kawinilah wanita-wanita (lain) yang kamu senangi: dua, tiga atau empat. Kemudian jika kamu takut tidak akan dapat berlaku adil, maka (kawinilah) seorang saja atau budak-budak yang kamu miliki, yang demikian itu adalah lebih dekat kepada tidak berbuat aniaya."6

Ayat tersebut dengan jelas menunjukan bahwa asas adanya perkawinan dalam Islam adalah monogami. Kebolehan poligami hanya apabila syarat-syarat yang dapat menjamin keadilan seorang suami kepada isteri terpenuhi, yaitu adil dan seimbang dalam nafkah, tempat tinggal, giliran malam, dan menjamin segala keperluan isteri. ${ }^{7}$ Adapun keadilan dalam membagi cinta dan kasih sayang tidak akan dapat terpenuhi sebagaimana disebutkan dalam al-Quran surat al-Nisa' ayat 129:

Artinya: "Dan kamu sekali-kali tidak akan dapat berlaku adil diantara isteri-isterimu walaupun kamu sangat ingin berbuat demikian, karena itu janganlah kamu terlalu cenderung (kepada yang kamu cintai) sehingga kamu biarkan yang lain terkatung-katung. Dan jika kamu mengadakan perbaikan dan memelihara diri (dari kecurangan) maka sesungguhnya Allah Maha Pengampun lagi Maha penyayang". 8

Dalam sebuah hadits Nabi saw. juga dijelaskan tentang orang yang berpoligami hanya terbatas empat orang isteri:

5 Jones Jamila, Monogami dan Poligami dalam Islam (Jakarta: Raja GrafindoPersada, 2001), hlm. 37.

${ }^{6}$ Departemen Agama, al-Qur'an dan Terjemahan, hlm. 115.

${ }^{7}$ Ibid. hlm. 114.

8 Ibid. hlm. 143. 


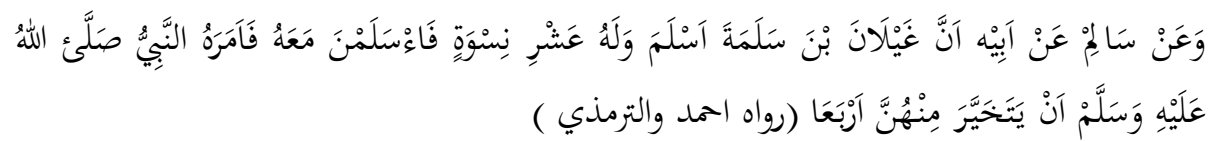

Artinya: "Dari Salim dari ayahnya bahwa Ghailani bin Salamah telah masuk Islam dan dia mempunyai sepuluh orang isteri lalu mereka masuk Islam bersamanya. Lalu Rasululah saw. memerintahkan agar dia memilih dari mereka empat orang saja". (HR. Ahmad, dan Tirmidzi). ${ }^{9}$

Atas dasar al-Qur'an dan Hadits itulah maka banyak kaum laki-laki tidak menutup rapat kemungkinan untuk berpoligami. Di dalam KHI (Kompilasi Hukum Islam) diatur tentang poligami pada pasal 55 yaitu: (1) Beristeri lebih dari satu orang pada waktu bersamaan terbatas hanya sampai empat orang isteri, (2) Syarat utama beristeri lebih dari satu orang, suami harus mampu berlaku adil terhadap isteri-isteri dan anak-anaknya, (3) Apabila syarat utama yang disebut pada ayat (2) tidak mungkin dipenuhi maka suami dilarang beristeri lebih dari satu orang. ${ }^{10}$

Beberapa alasan orang melakukan poligami yang dibenarkan oleh syara` seperti yang diamanatkan dalam UUP pasal 4 ayat (2) jo KHI pasal 57 apabila sebagai berikut: (1) Isteri tidak dapat menjalankan kewajibannya sebagai isteri/nusyuz, (2) Isteri mendapat cacat badan atau penyakit yang tidak dapat disembuhkan, (3) Isteri tidak dapat melahirkan keturunan. ${ }^{11}$

Banyak orang yang melakukan poligami tanpa dasar kuat yang dapat dibenarkan oleh syara' sehingga di dalam melakukan praktik poligami seorang laki-laki cenderung disebabkan karena faktor nafsu birahi saja. ${ }^{12}$ Persoalan laki-laki yang ingin berpoligami pada saat ini tidak semuanya dapat

\footnotetext{
${ }_{9}^{9}$ Mardani, Hadits Ahkam (Jakarta: PT. Raja GrafindoPersada, 2012 ), hlm. 269. 10 Siti Musawwamah, Hukum Perkawinan (Pamekasan: STAIN Pamekasan, 2010), hlm. 114-115.

11 UUP Pasal 41 ayat (2) jo KHI Pasal 57.

12 Amir Syarifuddin, Hukum Perkawinan Islam di Indonesia (Jakarta: Kencana Prenada Media Grup 2006), hlm. 130.
} 
persetujuan dari sang isteri yang pertama karena tidak mungkin isteri yang pertama rela menduakan hatinya dengan isteri yang kedua dari suaminya. Dan di sisi lain seseorang yang melakukan praktik poligami dikhawatirkan tidak berlaku adil dalam hal kasih sayang akan tetapi bisa dalam hal materi saja.

Berdasarkan pengamatan dan wawancara awal di Desa Laden Kecamatan Pamekasan Kabupaten Pamekasan, ada beberapa keluarga yang sebelumnya memang telah merajut hubungan keluarga yang baik seperti yang disyari'atkan agama diantaranya berinisial $\mathrm{SH}$ bersuami dengan $\mathrm{MN}, \mathrm{ZB}$ bersuami dengan MK, dan FM bersuami dengan RD. ${ }^{13}$ Akan tetapi dari beberapa pasangan itu pada akhirnya mengalami cobaan dalam kebersamaannya, karena disebabkan di-let $r e^{\prime}$. Sehingga sang suami menikah lagi tanpa sepengetahuan sang isteri pertama.

Salah satu penyebab terjadinya perkawinan (berpoligami) dikarenakan di-let $r e^{\prime}$. Sebelumnya, memang tidak ada niatan untuk melakukan poligami akan tetapi dengan disebabkan di-let $r e^{\prime}$ maka terjadilah perkawinan yang kedua dengan tidak menceraikan isteri pertamanya, sehingga pada akhirnya terjadilah praktik poligami yang ilegal. Di sisi lain sang suami masih mempunyai tanggung jawab yang besar dengan keluarga pertama (mempunyai ikatan perkawinan) dimana dengan adanya perkawinan dengan orang kedua berdampak kepada keharmonisan keluarga pertama yang sampai saat ini belum mendapatkan nafkah sama sekali padahal seharusnya memang menjadi tanggungannya. Sedangkan dalam Undang-Undang Nomor. 1 Tahun 1974 orang yang berpoligami salah satunya harus dapat persetujuan isteri pertama. Sementara tujuan dari adanya perkawinan itu adalah menciptakan keluarga yang sakinah (rasa tentram), mawaddah (cinta) dan rohmah (kasih sayang). Justru dalam praktik poligami akan menimbulkan banyak hal yang tidak sesuai

${ }^{13}$ Sun'ah (Warga Desa Laden), Wawancara (19 Maret 2013, Pukul 15.25). 
dengan tujuan adanya perkawinan apalagi seorang suami yang tanpa restu dari sang isteri dalam berpoligami.

Dari paparan yang telah dijabarkan di atas penulis tertarik untuk melakukan penelitian lebih lanjut tentang praktik poligami di bawah tangan yang terjadi di Desa Laden Kecamatan Pamekasan Kabupaten Pamekasan. Berpijak dari beberapa penjelasan di atas maka penulis dapat mengambil beberapa fokus masalah sebagai berikut: Pertama, Apa faktor penyebab terjadinya praktik poligami di bawah tangan di Desa Laden?; Kedua, Bagaimana pandangan UU No. 1 Tahun 1974 tentang praktik poligami di bawah tangan di Desa Laden?

\section{Deskripsi Let re'}

\section{Definisi Let re'}

Let $r e^{\prime}$ dalam istilah Madura adalah ramalan/guna-guna, yang dalam faktanya seseorang diramal melalui kartu atau daun dan melalui sarana lainnya dengan tujuan bagaimana seseorang itu bisa dijadikan sesuatu untuk dimilikinya. Sedangkan orang yang memiliki potensi me-let $r e^{\prime}$ hanya orang tertentu saja, dan mereka yang memiliki keahlian me-let $r e^{\prime}$ biasanya dianggap sakti dan hebat dan segala perkataannya selalu diyakini.

Sedangkan let $r e^{\prime}$ dalam istilah bahasa adalah dukun, yang artinya orang yang dapat memberitahukan segala sesuatu yang terjadi di masa yang akan datang dan mengaku dapat mengetahui rahasia-rahasia dan menerawang alam gaib. ${ }^{14}$

Dalam istilah Bahasa Arab, dukun disebut al-Kahin. Dan istilah lain adalah al-'Arraf (orang pintar/peramal), al-Sahir (tukang sihir), al-Munajjim (tukang ramal melalui perbintangan).

Dalam kultur budaya Indonesia, banyak pula pemakaian istilah yang kelihatanya no problem tetapi terkesan sebagai justifikasi agar boleh didatangi untuk mengatasi berbagai

14 al-Kunjurjani, Kitab al-Ta'Rifat (Singapura: al-Haramain, tt.), hlm. 177. 
problem seperti istilah orang pintar, orang tua, syaikh, ustadz, mentalist, paranormal, dan lain sebagainya. ${ }^{15}$

Dalam kamus al-Munjid, dukun adalah orang yang mengaku dan mengklaim dapat mengetahui rahasia-rahasia dan keadaan dalam gaib. Sedangkan menurut agama Yahudi dan penyembah berhala, dukun adalah orang yang selalu menyelesaikan orang dan memenuhi kebutuhannya dengan membuat ritual penyembelihan dan persembahan.

Sedangkan menurut al-Qardlawi dan al-Khathabi, dukun itu adalah orang yang memiliki pikiran tajam, berjiwa jahat, berkarekter panas lalu mereka dijinakkan oleh setan-setan karena adanya kecocokan diantara mereka dalam masalahmasalah tersebut dan setan itu juga memberikan pertolongan kepada mereka dengan segala kemampuan yang mereka miliki. ${ }^{16}$

\section{Ciri-Ciri Let re' (Dukun)}

Mengidentifikasi dukun sangat penting agar jelas bagi masyarakat siapa yang sedang mereka datangi, siapa yang sedang mereka mintai jasanya untuk berobat, mendapat kekayaan, jodoh, dan sebagainya. Karena sudah banyak yang menjadi korban, tertipu, dan disesatkan oleh orang-orang yang tidak bertanggungjawab yang terkadang mengaku sebagai Kyai atau ustadz. Untuk itu umat Islam perlu mengetahui ciri-ciri seorang dukun agar mereka dapat menghindarinya.

Ust. Fadlan Abu Yasir, Lc. dalam VCD-nya yang berjudul Membongkar Kesyirikan Dunia Perdukunan mengatakan ada beberapa ciri-ciri seorang dukun yang perlu diketahui. Hal yang sama juga dikatakan oleh Syaikh Wahid Abdussalam Bali, hanya saja Beliau melihat beberapa sifat dukun yang menjadi

15 Ibid. hlm. 178.

16Ibid. hlm.185 
ciri khas dukun Timur Tengah. ${ }^{17}$ Ciri-ciri dukun itu secara umum, antara lain adalah:

1) Menanyakan Nama Pasien dan Ibunya

Menanyakan nama pasien dan nama ibunya atau nama bapaknya, sesungguhnya biasa atau lazim dilakukan seorang dokter atau asistennya untuk mengisi kelengkapan data atau administrasi untuk tujuan pendataan. Namun bagi seorang dukun, menanyakan nama pasien dan ibunya bukan sekedar untuk pendataan, tetapi menjadi syarat pengobatan yang kemudian dikait-kaitkan dengan masalahmasalah gaib.

2) Menggunakan Barang Bekas Pasien

Meminta dan mengambil serta menggunakan benda bekas pasien sebagai sarana pengobatan merupakan sesuatu yang tidak logis dan jelas tidak syar'i. Apalagi kadang-kadang terkesan bahwa benda bekas itu digunakan untuk sesuatu yang bersifat pribadi dan tidak baik dipertontonkan kepada orang lain, seperti pakaian dalam wanita dan lain sebagainya. Setelah itu direndamkan di air lalu diminumkan dan sebagainya.

3) Meminta Binatang Tertentu

Meminta binatang tertentu dengan warna tertentu untuk disembelih, seperti ayam putih, kambing hitam, dan sebagainya. Biasanya binatang-binatang tersebut dijadikan sesajen atau persembahan untuk setan secara utuh, kepalanya atau darahnya yang dilumurkan di tubuh pasien atau tempat tertentu.

4) Menulis atau Memberikan Rajah, Wifiq, Isim, dan Hizib sebagai Jimat

Rajah dan sejenisnya biasanya dibuat oleh orang yang dipandang sebagai alim ulama' atau ustadz. Karena

17 Wahid Abdussalam Bali, ash-Sharim Battarfi at-Tashaddil as-Saharah al-Asyrar (Kairo: Maktabah at-Tabi' in, tt.), hlm. 31-36. 
seragamnya yang kelihatan Islami, orang beranggapan bahwa praktik yang dilakukan oleh ustadz atau kyai tersebut suatu kebenaran yang tidak bertentangan dengan syari'at. Padahal Islam tidak pernah mengajarkan ummatnya menggunakan rajah, wifiq, isim atau hizib sebagai penangkal badan agar terhindar dari gangguan setan, selamat dari bahaya atau sukses mendapatkan obsesi duniawi. Siapapun yang melakukan praktik seperti ini, maka ia dapat dikatakan dukun.

\section{Cara Kerja Let re' (Dukun)}

Sebagaimana telah dimaklumi sebelumnya bahwa perdukunan merupakan hal yang lazim dan biasa di zaman jahiliah, bahkan para dukun-dukun menjadi tempat bertanya dalam segala masalah dan kehidupan orang banyak. Hal ini disebabkan antara lain terputusnya mata rantai kenabian. Menurut al-Khathabi, 18 berdasarkan cara kerjanya, tipologi dukun ketika itu ada empat:

1) Dukun yang mendapatkan informasi dari jin. Sebab bangsa jin dahulunya dapat naik menembus langit untuk mendengarkan informasi, lalu mereka membisikkan berita itu kepada para dukun-dukun. Setelah Islam datang dengan diutusnya Nabi Muhammad saw. maka langit pun dijaga ketat sehingga setan-setan tidak leluasa naik kelangit. Kebenaran prediksi atau ramalan dukun sebelum Islam datang boleh dikatakan selalu jitu, tetapi setelah itu selalu meleset,

2) Dukun yang mendapatkan informasi dari jin dalam masalah-masalah yang biasanya tidak diketahui manusia kebanyakan,

3) Dukun yang bersandar kepada asumsi (zhan) dugaan (takhmin) semata.

${ }^{18}$ Ibid. hlm. 262. 
4) Dukun yang berpedoman kepada pengalaman (tajribah) dan kebiasaan (adat) semata.

\section{Hikmah Poligami}

Islam mengisyaratkan dan mengatur masalah praktik poligami sebagai upaya menghindari pengumbaran hawa nafsu seksual secara bebas dan perkembangan perzinahan. Islam menetapkan segala sesuatu yang dibutuhkan berdasarkan hukum alam dan perikemanusiaan, dengan mengubah segala sesuatu yang perlu diperbaiki dan menjamin segala sesuatu guna berdirinya suatu keadilan. Adapun hikmah yang dapat kita peroleh dari poligami dalam Islam, terbagi dalam tiga bagian; (1) Hikmah pengajaran/pendidikan, (2) Hikmah keadilan, (3) Hikmah sosial politik.

\section{Hikmah Pendidikan}

Tujuan poligami Rasullah saw. adalah untuk mencetak ibu-ibu pendidikan yang profesional mengajari wanita-wanita tentang hukum-hukum agama Islam yang hanif, terutama hukum yang berkaitan dengan masalah kewanitaan seperti masalah haid, nifas, janabah, thaharah, dan lain-lain. Seorang muslimah kala itu menghadapi kesulitan besar untuk menanyakan langsung soal-soal yang telah disebut di atas kepada Nabi Muhammad saw.

Apalagi Nabi Muhammad saw. adalah seorang hamba yang sangat pemalu yang tidak mungkin memberi penjelasan yang rinci tentang masalah kewanitaan. Terkadang Beliau harus menjawab pertanyaan itu dengan bahasa perumpamaan (kinayah). Sehingga sebagian wanita sulit memahami apa yang dimaksud Nabi Muhammad saw. dan sebagian lagi tidak berani bertanya langsung kepada Beliau karena malu. Dengan begitu alternatif yang sangat tepat adalah menjumpai para isteri Nabi saw. untuk meminta penjelasan.

\section{Hikmah Keadilan}

Hikmah dari segi keadilan dalam praktik poligami Rasullah saw. adalah bertujuan untuk menjaga hak-hak dan 
perbedaan yang 'azali karena hal ini sangatlah penting, sebab sebelum datangnya Islam, keadilan pada zaman jahiliyah tidak ada tempat dan perlindungan dalam segala aspek, seperti menjadikan anak angkat berkedudukan sama dengan anak kandung. Orang Arab sebelum Islam datang sering menjadikan anak angkat yang bukan darahnya sendiri sebagai anak kandungnya sendiri. ${ }^{19}$ Dengan demikian adanya perkawinan Rasullah saw. menjadi sarana membatalkan adat dan tradisi orang jahiliyah melalui perbuatan (praktik).

Dalam hal ini Nabi Muhammad saw. mengawini Zainab binti Jahsy yang merupakan mantan isteri anak angkatnya Zaid bin Haritsah berdasarkan isyarat dari Allah swt. bukan atas dorongan hawa nafsu dan syahwat sebagaimana yang dituding oleh musuh Islam. Maka perkawinan karena syari'at adalah harus diutamakan. Jika Rasullah saw. tidak mempraktikkannya maka manusia akan terus-menerus saling mewarisi kebiasaan jahiliyah sampai sekarang.

\section{Hikmah Sosial Politik}

Perkawinan Rasullah saw. dengan sebagian isterinya ditujukan untuk mempererat serta menguatkan hubungan sosial (masyarakat) satu sama lain berdasarkan perintah Islam dan kekeluargaan, seperti dengan para sahabat seperti Abu Bakar, Umar, Usman dan Ali untuk menyebarkan dan melancarkan dakwah Islam ke dalam lingkungan sosial yang lebih beragam.

Rasullah saw. menikahi Aisyah binti Abu Bakar, orang yang paling Beliau cintai dan hormati. Abu Bakar adalah orang yang telah menyerahkan jiwa dan hartanya dan banyak menanggung penderitaan dalam perjuangan Islam. Begitu pula pernikahan Beliau dengan Hafsah binti Umar ibnu Khattab dimana Allah swt. menguatkan Islam di tangannya, dia dikenal sangat tegas sebagai pembeda antara yang hak dan yang batil.

${ }^{19}$ Abdul Rahman Ghazali, Fiqih Munakahat (Jakarta: Kencana Prenada Media Grup, 2010), hlm. 136. 
Dengan begitu hubungan Rasullah saw. dengan dua sahabat besar itu melalui per-iparan sebagai penghormatan sosial untuk mereka dan sebagai balas jasa atas pengorbanan mereka dalam mengabdi kepada Islam dan umat Islam.

Dalam konteks hubungan politik, adalah untuk menyatukan hati keluarganya, sehingga dukungan dan bantuan mereka bisa dipakai untuk menyebarkan dakwah dan menegakkan Daulah Islamiah. ${ }^{20}$ Dalam praktik poligami, Rasullah saw. mengajari para sahabat untuk juga menghormati para wanita, melindungi anak-anak yatim sekaligus berbuat baik kepada mereka. Beliau menggambarkan jalan yang benar dalam berpoligami, yaitu tidak menjadikan hawa nafsu sebagai motivasi pokoknya. ${ }^{21}$

Adapun hikmah diizinkan berpoligami (dalam keadaan darurat dengan syarat berlaku adil) antara lain sebagai berikut :

1) Untuk mendapatkan keturunan bagi suami yang subur dan isteri yang mandul,

2) Untuk menjaga keutuhan keluarga tanpa menceraikan isteri pertama sekalipun isteri pertama tidak menjalankan fungsinya sebagai isteri, atau ia mendapat cacat badan atau penyakit yang tak dapat disembuhkan,

3) Untuk menyelamatkan suami yang hypersex dari perbuatan zina dan krisis akhlak lainnya,

4) Untuk menyelamatkan kaum wanita dari krisis akhlak yang tinggal di negara atau masyarakat yang jumlah wanitanya jauh lebih banyak dari kaum prianya.

Adapun hikmah dilarangnya menikah lebih dari empat isteri adalah sebagai berikut:

1) Batas maksimal beristeri bagi manusia biasa adalah empat isteri. Jika lebih dari empat isteri berarti

${ }_{20}$ Asghar Ali Engineer, Pembebasan Perempuan (Yogyakarta: PT. LkiS Pelangi Aksara, 2007), hlm. 108.

${ }^{21}$ Musfir, Poligami, hlm. 99-102. 
melampui batas kemampuan, baik dari segi kemampuan fisik mental maupun tanggung jawab, sehingga nantinya akan repot sendiri dan akhirnya akan mengalami ganguan kejiwaan (stres),

2) Karena melampui batas kemampuan, maka ia akan terseret melakukan kezaliman (aniaya) baik terhadap dirinya sendiri maupun terhadap para isteri-isterinya,

3) Manusia pada umumnya didominasi oleh nafsu syahwatnya, yang cenderung melakukan penyimpangan-penyimpangan, sehingga ia tidak mempunyai kekuatan untuk melakukan hak-haknya kepada isteri-isterinya. ${ }^{22}$

\section{Tinjauan Umum tentang Praktik Poligami di Bawah Tangan}

\section{Poligami di Bawah Tangan}

Perkawinan merupakan aspek yang penting dalam ssajaran Islam. Di dalam al-Quran dijumpai beberapa ayat yang berbicara tentang masalah perkawinan, baik yang memakai kata nikah (berhimpun) maupun mengunakan kata zawwaja (pasangan). Keseluruhannya memberikan tuntunan kepada manusia bagaimana seharusnya menjalani perkawinan agar perkawinan itu dapat menjadi jembatan yang mengantarkan manusia menuju kehidupan yang sakinah (damai, tenang, bahagia) yang diridhai Allah swt.

Pada sebagian masyarakat Islam, pelaksanaan poligami masih dilangsungkan dengan tidak mengindahkan aturan yang ada atau tanpa catatan resmi dari pihak yang berwenang. Kendatipun demikian agama ternyata tidak terlalu memperhatikan masyarakat yang melakukan poligami di bawah tangan, sehingga muncullah persoalan-persoalan di kemudian hari.

Ada sebagian orang yang melangsungkan pernikahan yang kedua, ketiga, bahkan keempat juga tanpa adanya

22 Ibid. hlm. 140. 
pemberitahuan kepada salah satu diantara isteri-isterinya, yang terpenting syarat dan rukunnya terpenuhi tanpa mencatatkan pernikahannya itu secara resmi kepada pihak yang berwenang. Poligami yang seperti ini dinamakan poligami di bawah tangan dan poligami yang seperti ini sah secara agama. ${ }^{23}$ Namun poligami ini tidak diakui secara Undang-Undang, dalam pengertian bahwa pernikahan itu tidak bisa dibuktikan dihadapan pihak berwenang kecuali dengan data dan catatan resmi. ${ }^{24}$

Poligami di bawah tangan merupakan perkawinan yang dilaksanakan dengan tidak memenuhi syarat dan prosedur peraturan perundang-undangan yang berlaku tanpa adanya persetujuan dari isteri-isterinya. Pernikahan yang seperti ini oleh sebagian masyarakat umum diartikan sebagai berikut:

1) Pernikahan tanpa wali. Pernikahan semacam ini dilakukan secara rahasia (sirri) dikarenakan pihak yang wali perempuan tidak setuju atau karena ingin memuaskan nafsu syahwat belaka tanpa mengindahkan lagi ketentuan syari'at Islam,

2) Pernikahan yang sah secara agama namun tidak dicatatkan dalam Lembaga Pencatat Negara. Banyak faktor yang menyebabkan seseorang tidak mencatatkan pernikahannya di Lembaga Pencatat Negara. Ada yang karena faktor ekonomi, ada pula yang disebabkan karena takut ketahuan melanggar aturan yang melarang Pegawai Negeri menikah lebih dari satu dan lain sebagainya,

3) Pernikahan yang dirahasiakan karena pertimbanganpertimbangan tertentu, misalnya karena takut mendapat stigma negatif dari masyarakat yang

23 Abd. Shomad, Hukum Islam Panorama Prinsip Syari'ah dalam Hukum Indonesia (Bandung: PT. Mizan Pustaka, 2005), hlm. 309.

24 Sayyid Ahmad al-Musayyar, Fiqih Cinta Kasih Rahasia Kebahagiaan Rumah Tangga (Erlangga: PT. Gelora Aksara Pratama, 2008), hlm. 142. 
terlanjur menganggap tabu pernikahan sirri, atau karena pertimbangan rumit yang memaksa seseorang untuk merahasiakan pernikahannya. ${ }^{25}$

Poligami di bawah tangan terkadang diartikan juga kawin sirri, yaitu perkawinan yang dilakukan secara diam-diam tanpa ada pemberitahuan kepada isteri-isterinya dan tanpa dicatatkan di lembaga negara yang berwenang. Perkawinan yang tidak berada di bawah pengawasan PPN (Pejabat Pencatat Nikah) itu dianggap sah secara syari'at Islam tetapi tidak mempunyai kekuatan hukum karena tidak memiliki bukti otentik perkawinan yang sah menurut UU yang berlaku di Indonesia.

Pencatatan perkawinan merupakan suatu bagian diantara aspek-aspek reformatif UUP dan KHI untuk merespon tuntutan dan kebutuhan perkembangan zaman dengan beberapa pertimbangan kemaslahatan. Diantaranya untuk mewujudkan ketertiban perkawinan dalam masyarakat, melindungi martabat, tujuan dan kesucian perkawinan, serta untuk melindungi derajat kemanusiaan dan kepentingan bagi kehidupan isteri dan anak keturunannya.

Dengan dilakukannya pencatatan nikah, maka peristiwa perkawinan dapat dibuktikan dengan adanya akta nikah. Masing-masing suami dan isteri mendapat salinannya, sebagai bukti bahwa mereka terikat pada jalinan perkawinan yang absah dan kuat. Apabila suatu ketika terjadi perselisihan atau percekcokan diantara mereka karena salah satu pihak tidak hendak bertanggungjawab atas keberlangsungan ikatan perkawinannya, maka akta nikah yang diperolehnya dapat dijadikan bukti formal untuk melakukan upaya hukum guna mempertahankan atau memperoleh hak-hak dirinya dari pihak

${ }_{25}$ Zainal Abidin, Fiqih Kontemporer (Pamekasan: STAIN Pamekasan, 2006), hlm. 26. 
lain. ${ }^{26}$ Dengan demikian, akta nikah bagi suami isteri berposisi sebagai bukti otentik untuk melakukan upaya hukum karena nyata-nyata telah terjadi ikatan hukum diantara mereka.

Ketentuan tentang pencatatan perkawinan diatur dalam UUP Pasal 2 ayat (2) dan KHI Pasal 5 dan 6. Dalam UUP Pasal 2 ayat (2) dinyatakan bahwa "Tiap-tiap perkawinan dicatat menurut peraturan perundang-undangan yang berlaku". 27 Sedangkan dalam KHI Pasal 5 disebutkan bahwa:

1) Agar terjamin ketertiban perkawinan bagi masyarakat Islam, setiap perkawinan harus dicatatkan,

2) Pencatatan perkawinan tersebut pada ayat 1 dilakukan oleh Pegawai Pencatat Nikah sebagaimana yang diatur dalam Undang-Undang No. 22 Tahun 1946 Jo UndangUndang No. 32 Tahun 1954. ${ }^{28}$

Di sisi lain dalam KHI pada Pasal 6 dinyatakan bahwa:

1) Untuk memenuhi ketentuan dalam Pasal 5, setiap perkawinan harus dilangsungkan di hadapan dan di bawah pengawasan Pegawai Pencatat Nikah,

2) Perkawinan yang dilakukan di luar pengawasan Pegawai Pencatat Nikah tidak mempunyai kekuatan hukum. ${ }^{29}$

Ada beberapa sebab, motif, dan alasan orang melakukan poligami di bawah tangan diantaranya adalah:

1) Terdapat pandangan maupun keyakinan keagamaan yang meneguhkan bahwa nikah lagi dapat dijadikan pilihan atau cara untuk menghindari terjadinya perzinahan. Pandangan itu diaktualisasikan kendati hal itu harus melanggar administrasi negara, ketertiban, dan kemaslahatan sosial,

\footnotetext{
26 Siti Musawwamah, Akseptabilitas Regulasi Kriminalitas Pelaku Kawin Sirri Menurut Pemuka Masyarakat Madura (Jakarta: Elmatera Publishing, 2012), hlm. 46.

27 UUP, hlm. 32.

28 KHI, hlm. 35.

29 Ibid. hlm. 36.
} 
2) Terdapat kesulitan administrasi hukum pada perkawinan antara orang pribumi (Indonesia) dengan orang asing yang berada di Indonesia. Akibatnya perkawinan di bawah tangan dipandang solusi yang dapat dilakukan untuk memperoleh keabsahan perkawinan,

3) Terdapat kesulitan yang relatif serius bagi laki-laki untuk memperoleh izin perkawinan dari isteri yang pertama agar dapat melangsungkan perkawinan dengan calon isteri kedua. Begitu pula terdapat peraturan perundangan (izin dari pengadilan) yang sulit untuk memberi kemungkinan kemudahan bagi suami yang hendak melangsungkan perkawinan dengan calon isteri yang kedua, ketiga, dan keempat,

4) Terjadinya peristiwa kehamilan di luar nikah dengan wanita lain. Jalan pintas untuk melakukan perkawinan poligami di bawah tangan yang tanpa ada pemberitahuan sebelumnya kepada isterinya. Tujuan utamanya, untuk menutupi rasa malu pihak orang tua, sanak kerabat, kenalan atau orang-orang yang ada disekitarnya. ${ }^{30}$

Empat sebab utama inilah cenderung melatarbelakangi atau menjadi alasan sebagian orang untuk menempuh jalan pintas melakukan pernikahan polgami di bawah tangan dengan tidak memperhatikan hal lain dalam berkeluarga.

\section{Metode Penelitian}

Secara etimologis, metodologi berasal dari bahasa Latin yang terdiri dari kata Metodos dan Logos. Metodos mempunyai arti cara atau jalan untuk memperoleh pengetahuan, sedangkan Logos berarti pikiran atau ilmu. Jadi secara terminologi adalah memberi pedoman tentang cara-cara seorang ilmuwan

\footnotetext{
${ }^{30}$ Ibid. hlm. 45.
} 
mempelajari, menganalisa dan memahami lingkunganlingkungan yang dihadapi. ${ }^{31}$

Secara lebih luas lagi dapat dipahami bahwa metodologi penelitian adalah ilmu yang mempelajari cara-cara melakukan pengamatan dengan pemikiran yang tepat secara terpadu melalui tahapan-tahapan yang disusun secara ilmiah menganalisis dan menyimpulkan data. Sehingga dapat dipergunakan untuk menemukan, mengembangkan dan menguji kebenaran suatu pengetahuan berdasarkan bimbingan Tuhan. ${ }^{32}$

Penelitian selanjutnya dilakukan oleh manusia untuk menyalurkan rasa ingin tahu yang telah mencapai taraf ilmiah, yang disertai keyakinan bahwa setiap gejala akan dapat ditelaah dan dicari hubungan sebab akibatnya atau kecendrungan yang timbul.

\section{Pendekatan dan Jenis Penelitian}

Dalam penelitian dikenal dengan dua pendekatan yang digunakan untuk melakukan penelitian yaitu pendekatan secara kualitatif dan pendekatan kuantitatif.

Pendekatan yang digunakan dalam penelitian ini adalah pendekatan kualitatif. Penelitian kualitatif ini cenderung bersifat deskriptif. Bogdan dan Taylor mendefinisikan pendekatan kualitatif sebagai prosedur penelitian yang menghasilkan data deskriptif berupa kata-kata tertulis/lisan dari orang-orang dan perilaku yang diamati. ${ }^{33}$ Sehingga dalam penelitian kualitatif ini lebih difokuskan terhadap fakta yang terjadi di lapangan dan landasan teori sebagai pemandu agar memperoleh kebenaran yang sesuai.

31 Bambang Sungguno, Metodologi Penelitian Hukum (Jakarta: PT. RajaGrafindo Persada, 2001), hlm. 27.

32 Ibid. hlm. 2.

33 Lexy J. Moleong, Metodologi Penelitian Kualitatif (Bandung: Remaja Rosdakarya, 2011), hlm. 6. 
Dalam penelitian kualitatif, identitas dan peran informan serta informasi-informasi yang disampaikan menjadi hal-hal yang berharga sehingga peneliti harus memiliki tanggungjawab untuk memperlakukan identitas diri dan informasi yang disampaikan oleh informan. Identitas dan informasi tersebut dapat dibuka atau tertutup untuk khalayak, tergantung dari kesepakatan antara peneliti dan informan yang tertulis dalam formulir kesepakatan (consent form). Peneliti boleh membuka identitas selama informan sepakat dan peneliti juga harus menghargai keputusan apabila informan ingin identitasnya dilindungi.

Sedangkan jenis penelitiannya, peneliti menggunakan jenis fenomenologi. Dimana peneliti mempunyai keinginan untuk mengungkapkan fenomena yang sedang berkembang di lapangan dan menjadi objek yang mempunyai daya ketertarikan untuk dijadikan suatu penelitian. Jenis fenomenologi ini merupakan kebenaran sesuatu itu dapat diperoleh dengan cara menangkap fenomena atau gejala yang memancar dari objek yang diteliti. ${ }^{34}$ Maka yang dimaksud dengan penelitian deskriptif fenomenologis adalah suatu jenis penelitian yang ditujukan untuk mendeskripsikan fenomenafenomena yang ada. Baik fenomena alamiah ataupun fenomena buatan manusia.

Berdasarkan data-data keseluruhan yang diperoleh di lapangan seperti yang sudah terungkap di atas tentang faktor penyebab para suami melakukan praktik poligami, khususnya kasus yang peneliti peroleh antara lain adalah karena seorang laki-laki dipandang sebagai sosok yang bertanggung jawab, penuh kasih sayang, dan perhatian terhadap keluarga, dan juga karena di-let re' (guna-guna) sehingga seorang laki-laki melakukan praktik poligami yang berujung tanpa tidak ada pemberitahuan terlebih dahulu kepada isteri-isterinya.

${ }^{34}$ Suharsimi Arikunto, Prosedur Penelitian: Suatu Pendekatan Praktik (Jakarta: Rienika Cipta, 2006), hlm. 14. 
Ada beberapa faktor yang melatarbelakangi masyarakat di Desa Laden dalam melakukan poligami di bawah tangan, antara lain:

1) Ekonomi, dalam artian seseorang tidak berkemampuan untuk membayar segala pembiayaan dalam mengurusi persyaratan mendaftar untuk melakukan poligami ke Pengadilan Agama setempat,

2) Pendidikan, dalam artian bahwa tak semuanya orang paham mengenai prosedur berpoligami yang benar yang ditetapkan dalam UU No. 1 Tahun 1974. Sehingga menjadi sangat rumit bagi orang yang tidak paham, sehingga jalan pintas sudah menjadi pilihannya (di bawah tangan),

3) Mengedepankan dasar agama daripada UU Negara,

4) Hal yang tidak biasa dilakukan oleh masyarakat di Desa Laden, dalam artian bahwa tidak semua orang yang ada di Desa Laden melakukan praktik poligami, hanya sebagian kecil saja yang melakukan.

Jadi kesimpulan dari keseluruhan data-data yang peneliti lakukan tidak ada satu pun praktik poligami yang terjadi di Desa Laden Kecamatan Pamekasan Kabupaten Pamekasan yang sesuai dengan ketetapan Undang-undang No. 1 Tahun 1974 tentang perkawinan yang berlaku di Indonesia, dan juga pelaksanaan praktik poligami yang berada di Desa Laden Kecamatan Pamekasan Kabupaten Pamekasan banyak dilakukan secara diam-diam ataupun lebih dikenal pernikahan sirri tanpa mengikuti peraturan yang ada di Indonesia.

Pandangan Undang-undang Nomor 1 Tahun 1974 tentang Praktik Poligami di Bawah Tangan di Desa Laden

Dalam perspektif Undang-Undang No. 1 Tahun 1974 kendatipun Undang-Undang Perkawinan menganut asas monogami seperti yang terdapat di dalam pasal 3 yang menyatakan bahwa "Seorang pria hanya boleh mempunyai seorang isteri dan seorang wanita hanya boleh mempunyai seorang suami", 
namun dalam bagian lain dinyatakan bahwa dalam keadaan tertentu praktik poligami dibenarkan. Klausul kebolehan poligami di dalam UUP sebenarnya hanyalah pengecualian, dan untuk itulah pasal tersebut mencantumkan alasan yang membolehkannya. ${ }^{35}$

Kaidah pada pasal 3 (1) tersebut agak mirip dengan bunyi pada pasal 27 KUHP (BW) yang mengatakan bahwa, "Dalam waktu yang sama seorang laki-laki hanya diperbolehkan mempunyai seorang perempuan sebagai isterinya, seorang perempuan hanya diperbolehkan mempunyai satu orang laki-laki suaminya".

Perbedaannya terletak pada pasal 3 (2) Undang-undang No. 1 Tahun 1974 yang menyatakan bahwa "Pengadilan dapat memberi izin kepada seorang suami untuk beristeri lebih dari seorang apabila dikehendaki oleh pihak-pihak yang bersangkutan". Dengan adanya pasal ini maka berarti Undang-undang No. 1 Tahun 1974 menganut asas poligami terbuka, oleh karena tidak tertutup kemungkinan dalam keadaan terpaksa suami melakukan poligami yang sifatnya tertutup atau poligami yang tidak begitu saja dapat dibuka tanpa pengawasan hakim.

Oleh karena itu, sebagaimana pada pasal 3 (2) UndangUndang No. 1 Tahun 1974 menyatakan di dalam penjelasannya bahwa "Pengadilan dalam memberi keputusan selain memeriksa apakah syarat yang tersebut pasal 4 dan 5 telah dipenuhi harus mengingat pula apakah ketentuan-ketentuan hukum perkawinan dari calon suami mengizinkan adanya poligami". Menurut Hazairin pada pasal 3 Undang-undang No. 1 Tahun 1974 ini merupakan contoh sebagai pembaharuan tafsir bagi umat Islam di Indonesia, dimana peraturan perundang-undangan yang setingkat derajatnya yang ditetapkan kemudian menghapus

35 Amir Nuruddin dan Azhari Akmal Tarigan, Hukum Perdata Islam di Indonesia (Jakarta: Prenada Media, 2004), hlm. 156. 
ketentuan-ketentuan yang berlawanan dalam perundangundangan sederajat yang mendahuluinya. ${ }^{36}$

\section{Alasan-alasan Poligami}

Karena pada prinsipnya suatu perkawinan seorang pria hanya boleh mempunyai seorang isteri, maka poligami diperbolehkan apabila dikehendaki oleh pihak-pihak yang bersangkutan, dan pengadilan telah memberi izin. Adapun alasan-alasan yang dipedomani oleh pengadilan untuk dapat memberi izin poligami, ditegaskan dalam pasal 4 (2) UndangUndang Perkawinan.

Pengadilan yang dimaksud dalam ayat 1 pasal ini hanya memberikan izin kepada seorang suami yang akan beristeri lebih dari seorang apabila:

1. Isteri tidak dapat menjalankan kewajibannya sebagai isteri,

2. Isteri terdapat cacat badan atau penyakit yang tidak dapat disembuhkan,

3. Isteri tidak dapat melahirkan keturunan. ${ }^{37}$

\section{Syarat-syarat Poligami}

Selain alasan-alasan di atas, untuk berpoligami syaratsyarat di bawah ini harus dipenuhi, menurut ketentuan pada pasal 5 Undang-Undang Perkawinan dijelaskan sebagai berikut: Untuk dapat mengajukan permohonan kepada pengadilan, sebagaimana dimaksud dalam pasal 4 ayat (1) Undang-Undang ini harus dipenuhi syarat-syarat sebagai berikut :

1. Adanya persetujuan dari isteri atau isteri-isteri,

2. Adanya kepastian bahwa suami mampu menjamin keperluan-keperluan hidup isteri-isteri dan anak-anak mereka,

36 Hilman Hadikusuma, Hukum Perkawinan Indonesia (Bandung: Mandar Maju, 2003), hlm. 34.

37 Undang-Undang No.1 Tahun 1974, Kompilasi Hukum Islam dan UndangUndang Perkawinan (Jakarta: Triniti, 2007), hlm. 90. 
3. Adanya jaminan bahwa suami akan berlaku adil terhadap isteri-isteri dan anak-anak mereka. ${ }^{38}$

Persetujuan yang dimaksud pada ayat (1) huruf a pasal ini tidak diperlukan bagi seorang suami apabila isteri atau isteri-isterinya tidak mungkin dimintai persetujuannya dan tidak dapat menjadi pihak dalam perjanjian, atau apabila tidak ada kabar dari isterinya selama sekurang-kurangnya 2 tahun, atau karena sebeb-sebab lainnya yang perlu mendapat penilaian dari hakim pengadilan. ${ }^{39}$

\section{Prosedur Poligami}

Pada pasal 40 Peraturan Pemerintah No. 9 Tahun 1975 menyebutkan bahwa "Apabila seorang suami bermaksud untuk beristeri lebih dari seorang maka ia wajib mengajukan permohonan secara tertulis kepada pengadilan". Dalam Kompilasi Hukum Islam diatur dalam pasal 56 sebagai berikut:

1. Suami yang hendak beristeri dari satu orang harus mendapat izin dari pengadilan setempat,

2. Pengajuan permohonan izin yang dimaksud pada ayat (1) dilakukan menurut tata cara sebagaimana diatur dalam Bab VIII Peraturan Pemerintah No. 9 Tahun 1975,

3. Perkawinan yang dilakukan dengan isteri yang kedua, ketiga, keempat, tanpa adanya izin dari Pengadilan Agama, tidak mempunyai kekuatan hukum. ${ }^{40}$

Pada pasal 57 KHI menyatakan bahwa Pengadilan Agama hanya memberikan izin pada suami yang akan beristeri lebih dari seorang apabila:

1. Isteri tidak dapat menjalankan kewajibannya sebagai isteri,

2. Isteri mendapat cacat badan atau penyakit yang tidak dapat disembuhkan,

\footnotetext{
38 Ibid. hlm. 90.

${ }^{39}$ Ahmad Rofiq, Hukum Islam di Indonesia, hlm. 171.

40 Kompilasi Hukum Islam, Kompilasi Hukum Islam dan Undang-Undang Perkawinan (Jakarta: Trinity, 2007), hlm. 21.
} 
3. Isteri tidak dapat melahirkan keturunan.

Pengadilan Agama setelah menerima permohonan izin poligami kemudian memeriksa:

1. Ada atau tidak adanya alasan yang memungkinkan seorang suami kawin lagi (pasal 41 huruf a) ialah meliputi keadaan seperti pasal $57 \mathrm{KHI}$ di atas,

2. Ada atau tidak adanya persetujuan dari istri, baik persetujuan lisan maupun tertulis, apabila persetujuan merupakan persetujuan lisan, persetujuan itu harus diucapkan di depan sidang/Pengadilan Agama,

3. Ada atau tidak adanya kemampuan suami untuk menjamin keperluan hidup isteri dan anak-anak, dengan memperlihatkan:

1) Surat keterangan mengenai penghasilan suami yang ditandatangani bendahara tempat bekerja, atau

2) Surat keterangan pajak penghasilan, atau

3) Surat keterangan lain yang dapat diterima oleh Pengadilan Agama.

Dalam ayat 2 pasal 58 KHI ditegaskan: "Dengan tidak mengurangi ketentuan pasal 41 huruf b PP No. 9 Tahun 1975, persetujuan isteri atau isteri-isteri dapat diberikan secara tertulis atau dengan lisan, tetapi sekalipun telah ada persetujuan tertulis, persetujuan ini dipertegas dengan persetujuan lisan isteri pada sidang Pengadilan Agama" ${ }^{41}$

\section{Temuan Penelitian dan Pembahasan}

Setelah peneliti melakukan penelitian dengan mengumpulkan data dan kemudian memaparkannya sesuai dengan yang diperoleh di lapangan, maka peneliti menemukan beberapa hal sebagai bentuk temuan penelitian.

Beberapa hasil temuan yang bisa dilaporkan dalam bentuk tulisan ini meliputi sebagai berikut:

1. Faktor penyebab terjadinya praktik poligami

${ }^{41}$ Ibid, hlm. 22 
1) Di sebabkan karena faktor dilet re' (guna-guna),

2) Dipandang sebagai sosok laki-laki yang bertanggung jawab, kasih sayang, dan perhatian terhadap keluarganya.

2. Pelaksanaanya dilakukan dengan cara diam-diam tanpa ada pemberitahuan terlebih dahulu kepada isteri pertamanya,

3. Poligami di bawah tangan disebabkan karena faktor:

1) Ekonomi, dalam artian seseorang tidak mampu untuk membayar segala pembiayaan dalam mengurusi persyaratan mendaftar untuk melakukan poligami,

2) Pendidikan, dalam artian rumitnya mengurusi prosedur berpoligami secara UU yang ditetapkan dalam UU No. 1 Tahun 1974,

3) Mengedepankan dasar agama daripada UU. Negara,

4) Hal yang tidak biasa dilakukan oleh masyarakat di Desa Laden, dalam artian bahwa tidak semua orang yang ada di Desa Laden melakukan praktik poligami namun hanya sebagian kecil saja yang melakukannya.

4. Pandangan Undang-Undang No. 1 Tahun 1974.

Menurut pandangan Undang-undang No.1 Tahun 1974 tentang Perkawinan, tentang pelaksanaan praktik poligami yang terjadi di Desa Laden Kecamatan Pamekasan Kabupaten Pamekasan sudah tidak sesuai dengan UndangUndang No. 1 Tahun 1974 yang berlaku di Indonesia tentang masalah perkawinan dan poligami. Dimana pelaksanaan praktik poligami yang terjadi di Desa Laden ini tanpa adanya pemberitahuan kepada isteri pertamanya, dan pelaksanaan perkawinannya dilakukan secara diam-diam yang disebabkan karena faktor di-let $r e^{\prime}$ (guna-guna), dan perkawinannya dilakukan secara diam-diam tanpa adanya pencatatan di Kantor Urusan Agama setempat.

Sementara pelaksanaannya, tentang praktik poligami yang terjadi di Desa Laden sama sekali tidak dibenarkan oleh Undang-undang No. 1 Tahun 1974 yang berlaku di Indonesia tentang masalah perkawinan dan poligami, untuk melakukan poligami seorang laki-laki harus memenuhi 
syarat yang diamanatkan oleh Undang-Undang No. 1 Tahun 1974 pada pasal 4 ayat 1 sebagai berikut:

1) Adanya persetujuan dari isteri/isteri-isteri,

2) Adanya kepastian bahwa suami mampu menjamin keperluan hidup isteri-isteri dan anak mereka,

3) Adanya jaminan bahwa suami akan berlaku adil terhadap isteri-isteri dan anak mereka.

Kemudian juga dalam Undang-Undang No. 1 Tahun 1974 memberikan penjelasan bahwa masalah yang disebut di atas (poligami) sebagaimana yang tercantum dalam KHI pada pasal 56 dan pasal 57 sebagai berikut:

1) Suami yang hendak beristeri dari satu orang harus mendapat izin dari pengadilan setempat,

2) Pengajuan permohonan izin yang dimaksud pada ayat (1) dilakukan menurut tata cara sebagaimana diatur dalam Bab VIII Peraturan pemerintah No. 9 Tahun 1975,

3) Perkawinan yang dilakukan dengan isteri yang kedua, ketiga, keempat, tanpa adanya izin dari Pengadilan Agama, tidak mempunyai kekuatan hukum. ${ }^{42}$

Pada pasal 57 KHI menyatakan bahwa Pengadilan Agama hanya memberikan izin pada suami yang akan beristeri lebih dari seorang apabila:

1) Isteri tidak dapat menjalankan kewajibannya sebagai isteri,

2) Isteri mendapat cacat badan atau penyakit yang tidak dapat disembuhkan,

3) Isteri tidak dapat melahirkan keturunan.

Jadi pada kesimpulannya, menurut pandangan UndangUndang No. 1 Tahun 1974 tentang masalah perkawinan dan poligami yang terjadi di Desa Laden sudah menyalahi aturan atau tidak dibenarkan menurut Undang-Undang yang berlaku di Indonesia.

42 Kompilasi Hukum Islam, Kompilasi Hukum Islam Dan Undang-Undang Perkawinan, hlm. 21. 
Dari apa yang telah dipaparkan di atas tampak bahwa masalah poligami merupakan masalah yang serius dan kontroversial yang menimbulkan pro dan kontra di tengah masyarakat. Pihak pro mendasarkan pada kaidah ketentuan agama. Sedangkan pihak yang kontra memandang poligami sebagai tindakan sewenang-wenang dan merupakan bentuk pengunggulan kaum laki-laki. Hal itu membuktikan bahwa ada sebagian masyarakat yang berada di sekililing mereka telah berhasil menyebar isu bahwa poligami adalah eksploitasi lakilaki atas kaum wanita yang hanya memburu pemuas hawa nahsu mereka.

Dalam pembatasan poligami menurut syari'at Islam terdapat dalam dua firman Allah swt. surat an-Nisa' ayat 3 dan 129. Kedua ayat tersebut cukup menjelaskan tentang hukum poligami dan batasan poligami antara lain; (1) Batasan poligami paling banyak hingga empat orang isteri, (2) Disyari'atkan jika dapat berbuat adil diantara isteri-isterinya, (3) Keadilan dimaksud mencakup keadilan dalam tempat tinggal, makan dan minum, serta perlakuan lahir batin, dan (4) Kemampuan suami dalam hal nafkah kepada isteri-isteri dan anak-anak mereka.

Tetapi meskipun Islam telah mengajarkan dan menetapkan hukum dan syarat serta alasan untuk melakukan poligami, namun banyak praktik poligami yang terjadi di Desa Laden Kecamatan Pamekasan Kabupaten Pamekasan tidak sesuai dengan Undang-Undang No. 1 Tahun 1974 yang sudah berlaku.

Dalam Undang-Undang No. 1 Tahun 1974 pada pasal 4 (2) ditetapkan bahwa alasan-alasan poligami yang dapat diterima apabila:

1. Isteri tidak dapat menjalankan kewajibannya sebagai isteri. Alasan ini tampak seperti sesuatu yang wajar tetapi kalau dicermati terasa aneh. Seorang isteri yang terikat dalam pernikahan mengalami ketidakmampuan dalam melaksanakan kewajiban sebagai seorang isteri. Pasti 
ketidakmampuan tersebut diakibatkan oleh adanya suatu penyakit, trauma atas suatu kejadian, atau hal lain yang menakutkan.

Dasar alasan bahwa isteri tidak dapat menjalankan kewajiban sebagai isteri harus dibuktikan dengan fakta, misalnya karena sakit sehingga tidak memungkinkannya melayani suaminya. Dengan demikian, hal tersebut tidak boleh ditentukan secara sepihak oleh suami agar memungkinkan ia beristeri lagi ataupun rekayasa kesepakatan kedua belah pihak.

2. Isteri mendapat cacat badan atau penyakit yang tidak dapat disembuhkan.

Alasan kedua yang memperbolehkan seorang laki-laki berpoligami adalah jika si isteri memiliki cacat badan atau memiliki penyakit yang tidak dapat disembuhkan lagi. Sebenarnya kenyataan ini menyakitkan dan dianggap tidak adil. Pada saat dia menghadapi cobaan besar, mengalami suatu kecelakaan atau penyakit yang mengakibatkan cacat badan atau penyakit yang sulit disembuhkan, isteri harus merelakan suami yang dicintainya menikmati kebahagiaan dengan perempuan lain.

3. Isteri tidak dapat melahirkan keturunan. ${ }^{43}$

Memiliki keturunan dari sebuah pernikahan merupakan harapan hampir semua pasangan suami isteri. Melalui kelahiran seorang anak diharapkan akan menjadi tali penyambung keturunan selanjutnya. Selain itu kelahiran seorang anak dianggap merupakan sumber kebahagiaan berkeluarga, anak sering kali menjadi penyambung tali kasih yang erat antara suami isteri. Oleh karena itu, banyak suami isteri menjadi kecewa ketika mengetahui pasangannya tidak mungkin memberikan anak yang akan menjadi tumpahan harapan dan kebahagiaan. Dengan demikian seakan menjadi

43 Undang-Undang Perkawinan, Undang-Undang Perkawinan dan Kompilasi Hukum Islam, hlm. 90. 
wajar jika seorang suami menuntut diperbolehkan menikah lagi karena ketidakmampuan isteri melahirkan seoarang anak.

Apabila diperhatikan, alasan-alasan tersebut di atas mengacu kepada tujuan pokok perkawinan itu dilaksanakan, yakni membentuk keluarga yang bahagia dan kekal berdasarkan Ketuhanan Yang Maha Esa, atau dalam rumusan Kompilasi Hukum Islam disebut dengan membentuk keluarga yang sakinah (rasa tentram), mawaddah (cinta) dan rahmah (kasih sayang).

Pada sebagian masyarakat yang ada di Desa Laden, pelaksanaan praktek poligami masih dilangsungkan dengan tidak mengindahkan aturan yang ada dalam UU No. 1 Tahun 1974. Kendatipun demikian agama ternyata tidak terlalu memperhatikan masyarakat yang melakukan poligami di bawah tangan, sehingga muncullah persoalan-persoalan di kemudian hari.

Ada sebagian orang yang melangsungkan pernikahan yang kedua, ketiga, dan keempat juga tanpa pemberitahuan kepada salah satu diantara isteri-isterinya. Yang terpenting syarat dan rukunnya terpenuhi namun tanpa mencatatkan pernikahannya itu secara resmi kepada pihak yang berwenang. Poligami yang seperti ini dinamakan poligami di bawah tangan dan poligami yang seperti ini sah secara agama. ${ }^{44}$ Namun poligami yang ini tidak diakui secara Undang-Undang, dalam pengertian bahwa pernikahan itu tidak bisa dibuktikan di hadapan pihak berwenang kecuali dengan data dan catatan resmi. ${ }^{45}$

Dengan dilakukannya pencatatan nikah, maka peristiwa perkawinan dapat dibuktikan dengan adanya akta nikah.

44 Abd. Shomad, Hukum Islam Panorama Prinsip Syari'ah Dalam Hukum Indonesia, hlm. 309.

45 Sayyid Ahmad al-Musayyar, Fiqih Cinta Kasih Rahasia Kebahagian Rumah Tangga, hlm. 142. 
Masing-masing suami dan isteri mendapat salinannya, sebagai bukti bahwa mereka terikat pada jalinan perkawinan yang absah dan kuat. Apabila suatu ketika terjadi perselisihan atau percekcokan diantara mereka karena salah satu pihak tidak hendak bertanggungjawab atas keberlangsungan ikatan perkawinannya, maka akta nikah yang diperolehnya dapat dijadikan bukti formal untuk melakukan upaya hukum guna mempertahankan atau memperoleh hak-hak dirinya dari pihak lain. ${ }^{46}$ Dengan demikian, akta nikah bagi suami isteri berposisi sebagai bukti otentik untuk melakukan upaya hukum karena nyata-nyata telah terjadi ikatan hukum diantara mereka.

Ketentuan tentang pencatatan perkawinan diatur dalam UUP pasal 2 ayat (2) dan KHI Pasal 5 dan 6. Dalam UUP pasal 2 ayat (2) dinyatakan bahwa "Tiap-tiap perkawinan dicatat menurut peraturan perundang-undangan yang berlaku". ${ }^{47}$ Sedangkan dalam KHI pasal 5 disebutkan bahwa: (1) Agar terjamin ketertiban perkawinan bagi masyarakat Islam, setiap perkawinan harus dicatatkan, dan (2) Pencatatan perkawinan tersebut pada ayat 1 dilakukan oleh Pegawai Pencatat Nikah sebagaimana yang diatur dalam Undang-Undang No. 22 Tahun 1946 Jo UndangUndang No. 32 Tahun $1954 .{ }^{48}$

Di sisi lain dalam KHI pada pasal 6 dinyatakan bahwa: (1) Untuk memenuhi ketentuan dalam pasal 5 setiap perkawinan harus dilangsungkan di hadapan dan di bawah pengawasan pegawai pencatat nikah; (2) Perkawinan yang dilakukan di luar pengawasan Pegawai Pencatat Nikah tidak mempunyai kekuatan hukum. ${ }^{49}$

Praktik poligami yang terjadi di Desa Laden Kecamatan Pamekasan Kabupaten Pamekasan, yang dilakukan oleh suami

\footnotetext{
46 Siti Musawwamah, Akseptabilitas Regulasi Keriminalitas Pelaku Kawin Sirri Menurut Pemuka Masyarakat Madura, hlm. 46.

47 UUP, hlm. 32.

48 KHI, hlm. 35.

${ }^{49}$ Ibid. hlm. 36.
} 
(pelaku poligami) sama sekali tidak termasuk salah satu alasan yang telah ditetapkan oleh Undang-Undang No. 1 Tahun 1974 pasal 4 ayat 2. Pelaku poligami di Desa Laden Kecamatan Pamekasan Kabupaten Pamekasan, kebanyakan berdasarkan belas kasihan yang dijadikan sebagai alasan untuk melakukan praktik poligami selain karena disebabkan faktor di-let $r e^{\prime}$ (guna-guna).

Orang yang terkena let $r e^{\prime}$ akan memperlihatkan beberapa tanda perubahan yang umumnya tidak wajar dan secara jelas dapat dilihat perbandingan perubahan perilaku dari sikap keseharian orang tersebut. Umumnya yang terkena pengasihan itu adalah kaum wanita, namun tidak menutup kemungkinan para pria juga terkena ilmu guna-guna ini dengan cara di-let re'.

Dari hasil wawancara dan pengamatan yang dilakukan oleh peneliti di Desa Laden untuk membuktikan bahwa memang terjadi poligami yang disebabkan karena di-let $r e^{\prime}$, maka peneliti menggunakan metode triangulasi sumber. Dari data yang diperoleh menunjukan bahwa sebagian masyarakat di Desa Laden yang terkena guna-guna tersebut memang dalam pergaulan kesehariannya sudah berbeda dari biasanya. Diantara tanda-tanda tersebut adalah sering termenung, sering berbicara sendiri, terlalu terobsesi pada seseorang sampai kehilangan akal sehat, suka meneteskan air mata atau tertawa sendiri tanpa sebab yang pasti, sering menyebut nama seseorang yang disenangi, sering terbangun di malam hari dan kebingungan/gelisah, hilangnya nafsu makan, suka menyendiri dan tidak nyambung apabila diajak bicara.

Sedangkan apabila ditinjau dari Undang-Undang No. 1 Tahun 1974, maka praktik poligami yang terjadi di Desa Laden Kecamatan Pamekasan Kabupaten Pamekasan, tidak sesuai dengan ketentuan Undang-undang yang ditetapkan. Poligami di bawah tangan merupakan perkawinan yang dilaksanakan dengan tidak memenuhi syarat dan prosedur peraturan 
perundang-undangan yang berlaku tanpa adanya persetujuan dari isteri-isterinya.

Adapun syarat-syarat untuk melakukan poligami dalam Undang-Undang Pasal 5 ayat (1) telah dijelaskan bahwa:

1. Adanya persetujuan dari isteri-isteri. Pada hakikatnya, sulit bagi seorang perempuan untuk menerima kenyataan berbagi dengan perempuan lain dalam kehidupan rumah tangganya. Kenyataan tersebut sangat manusiawi karena hal yang sama akan dialami pula oleh seorang laki-laki. Oleh karena itu, penting sekali adanya persetujuan terlebih dahulu dari isteri untuk merelakan suaminya berpoligami. Hendaknya persetujuan tersebut dilakukan dengan penuh kesadaran, keikhlasan, dan tanpa adanya unsur pemaksaan,

2. Adanya kepastian bahwa suami mampu menjamin keperluan hidup isteri dan anak-anak mereka. Syarat ini mungkin tidak terlalu sulit dilakukan kalau suami memiliki kemampuan di bidang materi yang cukup, sehingga memungkinkan untuk terus memberikan kewajiban nafkah untuk para isteri dan anaknya. Kepastian jaminan dari suami untuk memenuhi kebutuhan isteri dan anaknya harus ditegaskan dalam suatu perjanjian dan memperhatikan keterangan penghasilan yang ditandatangani oleh bendahara tempat suami bekerja dan surat keterangan lain yang dapat diterima oleh pengadilan setempat,

3. Adanya jaminan bahwa suami akan berlaku adil terhadap isteri-isteri dan anak-anaknya. Syarat ketiga tentang masalah keadilan ini sangat penting untuk menjaga perasaan isteri dan anaknya melalui adanya perlakuan yang tidak diskriminatif. Tindakan adil tersebut meskipun mudah diucapkan, sangat sulit diwujudkan.

Menurut pandangan peneliti, dianutnya asas monogami dalam ketentuan pada pasal 3 ayat 1 Undang-Undang Perkawinan mencerminkan pengutamaan diterapkannya asas monogami dalam setiap perkawinan. Namun dalam hal kondisi tertentu dan keadaan darurat dimungkinkan adanya poligami 
dapat dibenarkan dengan dasar alasan yang ketat dan persyaratan yang sangat berat.

Dengan demikian dari aspek ketentuan hukumnya Undang-Undang Perkawinan tersebut sudah cukup baik dalam artian secara tegas ditentukan bahwa pada dasarnya menganut asas monogami, akan tetapi dalam keadaan tertentu asas tersebut bisa jadi tidak lagi diindahkan oleh sebagian masyarakat dengan memperhatikan situasi dan kondisi tertentu. Dengan kata lain, bahwa poligami bisa dilakukan tetapi sebagai upaya terakhir jika semua upaya penyelesaian lain telah dicoba.

Namun dalam kenyataanya praktik poligami yang terjadi di Desa Laden Kecamatan Pamekasan Kabupaten Pamekasan yaitu praktik poligami liar yang sama sekali tidak dibenarkan menurut aturan yang berlaku di Indonesia. Adapun pelaksanaannya dilakukan secara diam-diam tanpa dicatatkan kepada Pejabat Pencatat Nikah setempat.

Ada beberapa faktor yang melatarbelakangi masyarakat di Desa Laden dalam melakukan poligami di bawah tangan yakni: Pertama, Ekonomi, dalam artian seseorang tidak berkemampuan untuk membayar segala pembiayaan dalam mengurusi persyaratan mendaftar untuk melakukan poligami ke Pengadilan Agama setempat; Kedua, Pendidikan, dalam artian bahwa tak semuanya orang paham mengenai prosedur berpoligami yang benar yang ditetapkan dalam UU No. 1 Tahun 1974. Sehingga menjadi sangat rumit bagi orang yang tidak paham, sehingga jalan pintas sudah menjadi pilihannya (di bawah tangan); Ketiga, Mengedepankan dasar agama dari pada UU Negara; Keempat, Hal yang tidak biasa dilakukan oleh masyarakat di Desa Laden, dalam artian bahwa tidak semua orang yang ada di Desa Laden melakukan praktik poligami hanya sebagian kecil saja yang melakukan, sehingga merupakan hal yang tidak biasa, maka dari ketidakbiasaan ini orang cenderung melakukan praktik nikah di bawah tangan. 


\section{Penutup}

Dari beberapa penjelasan di atas dapat ditarik suatu kesimpulan oleh penulis bahwa: Pertama, Faktor yang melatarbelakangi terjadinya praktik poligami di Desa Laden Kecamatan Pamekasan Kabupaten Pamekasan, disebabkan karena di-let re' (guna-guna). Adapun praktik poligami yang terjadi di Desa Laden Kecamatan Pamekasan Kabupaten Pamekasan belum sesuai dengan Undang-Undang No. 1 Tahun 1974, dimana sebagian masyarakat Desa Laden melakukan praktik poligami secara tidak resmi atau diam-diam, dan tanpa adanya pemberitahuan kepada isteri pertamanya.

Kedua, Sedangkan dalam tinjauan Undang-Undang No. 1 Tahun 1974 tentang adanya praktik poligami di bawah tangan di Desa Laden Kecamatan Pamekasan tidak sesuai dengan perundang-undangan yang berlaku karena tanpa melakukan proses perizinan terlebih dahulu oleh suami yang hendak berpoligami terhadap isteri atau isteri-isterinya dan tanpa melalui izin dari Pengadilan Agama setempat

\section{Daftar Pustaka}

Abidin, Zainal. Fiqih Kontemporer. Pamekasan: STAIN Pamekasan, 2006.

Aibak, Kutbuddin. Kajian Fiqih Kontemporer. Surabaya: eLKAF, 2006

Arikunto, Suharsimi. Prosedur Penelitian: Suatu Pendekatan Praktik. Jakarta: Rienika Cipta, 2006.

Bali, Abdussalam Wahid. ash-Sharim Battarfi at-Tashaddil asSaharah al-Asyrar. Kairo: Maktabah at-Tabi'in,tt.

Buna'i. Metodologi Penelitian Pendidikan. Pamekasan: STAIN Press, 2006.

Departemen Agama. al-Qur'an dan Terjemahan. Surabaya: Alhidayah, 1998.

Engineer, Asghar Ali. Pembebasan Perempuan. Yogyakarta: PT. LkiS Pelangi Aksara, 2007. 
Ghozali, Abdul Rahman. Fiqih Munakahat. Jakarta: Prenada Media Group, 2010.

Istibsyaroh. Poligami dalam Cita dan Fakta. Jakarta: PT. Mizan Publika, 2004.

Jamila, Jones. Monogami dan Poligami dalam Islam. Jakarta: PT. RajaGranfindo Persada, 2001.

Kunjurjani al-. Kitab at-Ta'Rifat. Singapura: al-Haramain, tt.

Machali, Rochayah. Wacana Poligami di Indonesia. Bandung: PT. Mizan Pustaka, 2005.

Mardani. Hadits Ahkam. Jakarta: PT. RajaGrafindo Persada, 2012.

Moleong, Lexy J. Metodologi Penelitian Kualitatif. Bandung: Remaja Rosdakarya, 2011.

Musawwamah, Siti. Akseptabilitas Regulasi Keriminalitas Pelaku Kawin Sirri Menurut Pemuka Masyarakat Madura. Jakarta: Elmatera Publishing, 2012. . Hukum Perkawinan. Pamekasan: STAIN

Pamekasan, 2010.

Musayyar al-, Sayyid Ahmad. Fiqih Cinta Kasih Rahasia Kebahagian Rumah Tangga. Erlangga: PT. Gelora Aksara Pratama, 2008.

Satori, Djam'an. Metodologi Penelitian Kualitatif. Bandung: Alfabeta, 2009.

Shihab, M. Quraish. Perempuan. Jakarta: Lentera Hati , 2010.

Shomad, Abd. Hukum Islam Panorama Prinsip Syari'ah dalam Hukum Indonesia. Bandung: PT. Mizan Pustaka, 2005.

Sugiyono. Metode Penelitian Pendidikan: Pendekatan Kuantitatif, Kualitatif. Bandung: Alfabeta, 2011.

Sungguno, Bambang. Metodologi Penelitian Hukum. Jakarta: PT. RajaGrafindo Persada, 2001.

Supriyadi, Dedi. Perbandingan Hukum Perkawinan di Dunia Islam. Bandung: Pustaka Al-Fikris, 2009.

Syaltut, Syekh Mahmud. Akidah dan Syari'ah Islam. Jakarta: Bumi Aksara, 1994.

Syamwil, Beryl. Kiprah Muslimah dalam Keluarga Islam. Bandung: Mizan Khazanah Ilmu Islam, 1978. 
Syarifuddin, Amir. Hukum Perkawinan Islam di Indonesia. Jakarta: Kencana Prenada Media Grup, 2006.

Tihani dan Sohari Saharani. Fiqih Munakahat. Jakarta: PT. Raja Grafindo Persada, 2010.

Usamah, Abu 'Ubaidah bin Muhammad al-Jamal. Shahih Fiqih Wanita, terj. Arif Rahman Hakim. Surabaya: Penerbit Insan Kamil, tt.

UUP Pasal 41 ayat (2) jo KHI Pasal 57

Yasin, Fatihuddin Abul. Risalah Hukum Nikah. Surabaya: Tertib Terang, 2006.

Zenref. Realitas Keluarga Muslim Antara Mitos dan Doktin Agama. Malang: UIN Malang, 2008. 